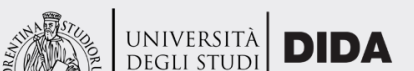

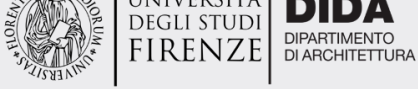

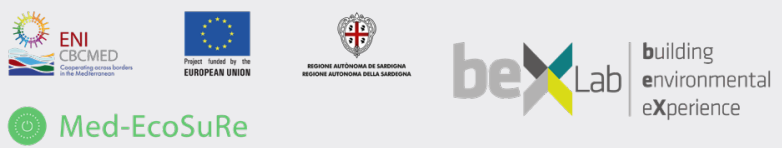

etaflorence : renewableenergies Springer

\section{CONFERENCE TOPICS}

1. Mediterranean Health Cities and Green Architecture

2. Urban Resilience and Climate Change

3. Deep Renovation of Historical Buildings

4. Green Technologies \& Nature-Based Solutions

5. Eco and Recycled Materials

6. Biomimicry and Adapting Buildings

7. Renewable Energies in Building \& Energy Communities

8. Human Pro-Active Behaviours \& Energy Consciousness

9. Predictive Design and Monitoring Systems

10. Environmental Comfort and Wellbeing

11. Urban Farming and Urban Forest

12. Policy Education, Training and Finance

Speciall Call for student awareds

\section{KEY DATES}

Abstract Submission: 31 MARCH 2022

Final Paper Submission: 20 MAY 2022

Forum Programme: 30 JUNE 2022

Forum Proceedings: 30 SEPTEMBER 2022

\section{ORGANIZING COMMITTEE}

Prof. Antonella Trombadore

Chair of technical committee

Dott. Angela Grassi

Chair of organizing committee

Arch. Gisella Calcagno (PhD)

Arch. Juan Camilo Olano (MSc)

Arch. Lucia Montoni

\section{MED \\ GREEN

MEDITERRANEAN ARCHITECTURE \&

GREEN-DIGITAL TRANSITION

'-...-......

Prof. Ali Sayigh

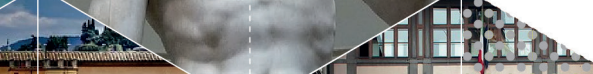

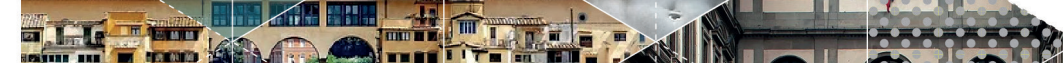

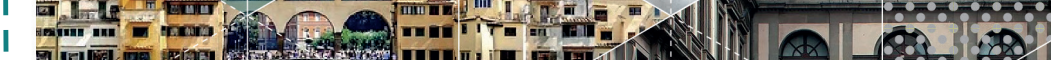

i
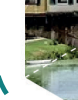

(1)

WEB SITE

Chair of the Forum \& Chair of the Scientific Committee
Prof. Saverio Mecca
Conference Chair - Host Institution
Prof. Marco Salla
Honorary Co-chair of Scientific Committee

Chair of the Forum \& Chair of the Scientific Committee
Prof. Saverio Mecca
Conference Chair - Host Institution
Prof. Marco Salla
Honorary Co-chair of Scientific Committee

Chair of the Forum \& Chair of the Scientific Committee
Prof. Saverio Mecca
Conference Chair - Host Institution
Prof. Marco Salla
Honorary Co-chair of Scientific Committee

Chair of the Forum \& Chair of the Scientific Committee
Prof. Saverio Mecca
Conference Chair - Host Institution
Prof. Marco Sala
Honorary Co-chair of Scientific Committee
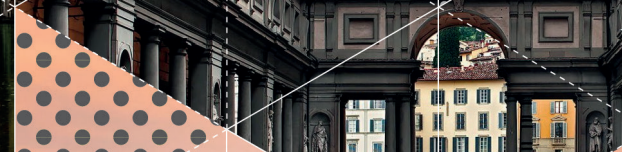

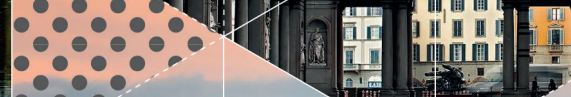
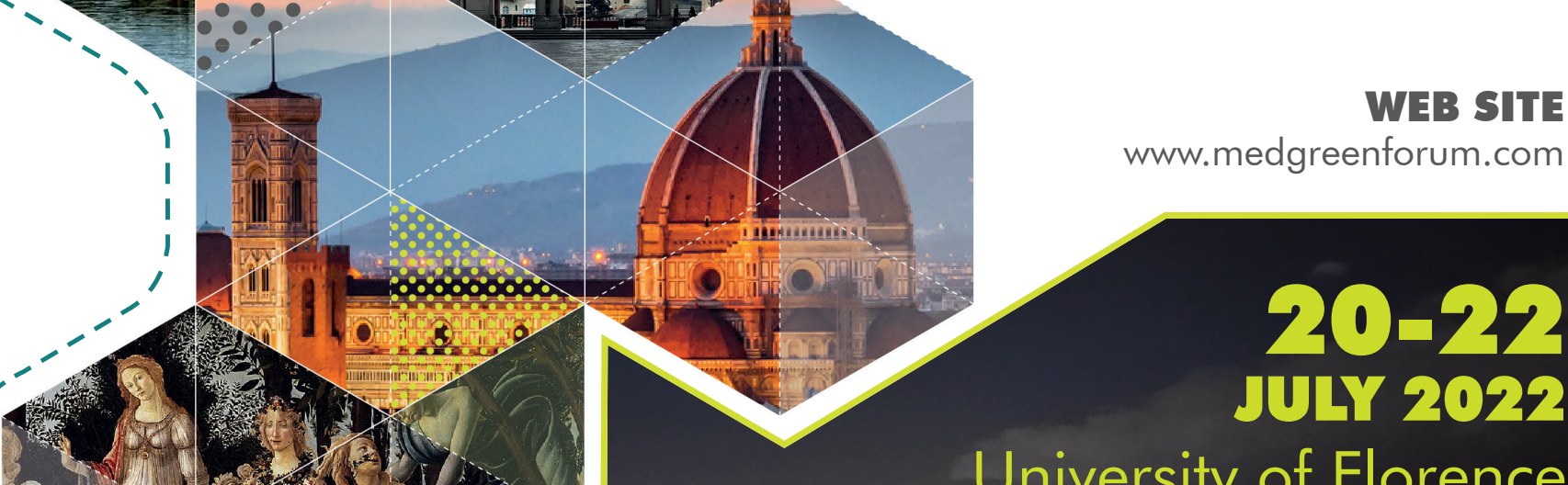

University of Florence

DIDA Department of Architecture
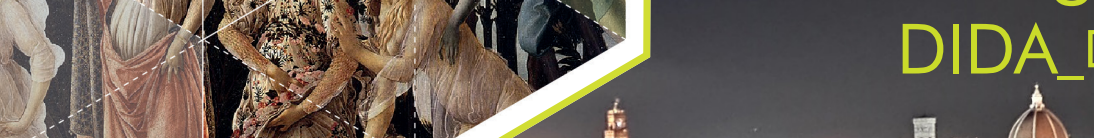